\title{
Kemampuan Analisis Peserta Didik Terhadap Materi Pencemaran Lingkungan Melalui Lembar Kerja Inovatif
}

\author{
Yula Miranda ${ }^{1}$, Agus Sadono ${ }^{1}$, Nuriman wijaya ${ }^{1}$, Gress Melinda \\ Pangaribuan $^{1}$, Erlina Kalawa ${ }^{1}$, Gugun Nurwaid ${ }^{1}$, Marete ${ }^{2}$ \\ ${ }^{1}$ Pendidikan Biologi, Pendidikan MIPA, Fakultas Keguruan Dan Ilmu Pendidikan, \\ Universitas Palangka Raya, Indonesia \\ ${ }^{2}$ SMA Kristen Palangka Raya, Indonesia \\ Email Author: yulamiranda@gmail.com
}

Diterima: 12-11-2021; Diperbaiki:01-12-2021; Disetujui:10-12-2021

\begin{abstract}
ABSTRAK
Permasalahan penelitian ini akibat adanya kesenjangan antara harapan KD dengan indikator yang ingin dicapai. Tujuan penelitian menghasilkan Lembar Kerja Peserta Didik Berbasis Masalah yang dapat meningkatkan kemampuan analisis materi pencemaran lingkungan, berupa kemampuan analisis elemen, menganalisis hubungan, dan analisis pengorganisasian prinsip dengan menggunakan kata kerja operasional menganalisis, mendeteksi, mendiagnosis, menguji, memecahkan, mengkorelasikan, mendiagramkan, menyimpulkan, menemukan, dan melatih. Metode penelitian dengan model pengembangan ADDIE meliputi analisis, desain, pengembangan, implementasi, dan evaluasi. Kemampuan yang dihasilkan dalam lembar kerja peserta didik pada penelitian ini termasuk dalam berpikir tingkat tinggi yang disesuaikan dengan kompetensi dasar pada materi pencemaran lingkungan di Kurikulum sekolah, kemampuan analisis dan kemampuan identifikasi, mengkorelasikan suatu konsep pencemaran. Penelitian menghasilkan produk LKPD hasil pengembangan dan luaran yang dihasilkan karya ilmiah kategori artikel ilmiah dimuat di jurnal nasional terakreditasi dan HKI hak cipta. Hasil penelitian dapat mengaktifkan peserta didik untuk menganalisis masalah pada materi pencemaran lingkungan dan LKPD berkontribusi sangat baik sebagai media, sumber belajar bagi peserta didik. Lembar kerja peserta didik berbasis masalah dapat meningkatkan kemampuan peserta didik menganalisis masalah di kelas X-MIPA dengan N-Gain 0,86 kategori tinggi, sedangkan di kelas X-IIS Peminatan terjadi peningkatan kemampuan analisis dengan N-Gain 0,42 berada pada kategori sedang.
\end{abstract}

Kata kunci: LKPD, kemampuan analisis, pencemaran lingkungan

\section{PENDAHULUAN}

Hasil analisis awal pembelajaran pencemaran lingkungan pada ditemukan adanya kesenjangan antara harapan kurikulum dengan fakta yang dicapai pada indikator pembelajaran. Permasalahan penting untuk dicari solusinya. agar peserta didik terlatih untuk berpikir tingkat tinggi sesuai kompetensi dasar dalam kurikulum yang berlaku.. Kemampuan menganalisis adalah kata kerja operasional berada pada kemampuan berpikir tingkat tinggi. Manfaat teoritis pengembangan lembar kegiatan peserta didik (LKPD) agar memudahkan peserta didik dan guru melakukan kegiatan belajar mengajar., memberi kesempatan peserta didik untuk lebih mengeksplorasikan berdasarkan kemampuannya, sehingga tercipta belajar 
lebih mandiri dan hal ini akan mengubah orientasi belajar yang semula berpusat pada guru, kemudian berubah menjadi berpusat pada kegiatan peserta didik sendiri. Masalah ini selalu terjadi di sekolah yang belum melaksanakan dan menemukan alternatif pembelajaran yang berpusat pada peserta didik..

Salah satu solusi yang dapat memecahkan permasalahan penelitian ini dengan menemukan perangkat pembelajaran yang mampu mengubah cara berpikir peserta didik, di antaranya mendesain LKPD yang inovatif sesuai kompetensi dasar yang diharapkan dalam kurikulum yang berlaku. Tujuan penelitian ini untuk mendesain LKPD yang inovatif, valid, praktis, dan efektif serta untuk meningkatkan kemampuan analisis peserta didik. Tahapan pengembangan LKPD melalui model analisis, desain, pengembangan, implementasi, dan evaluasi. Output hasil penelitian adalah LKPD inovatif hasil pengembangan dan luaran yang dihasilkan karya ilmiah kategori artikel ilmiah dimuat di jurnal nasional terakreditasi dan HKI hak cipta.

Implikasi lembar kerja peserta didik berbasis masalah dapat meningkatkan kemampuan analisis peserta didik materi pencemaran lingkungan, bahkan dapat meningkatkan kemampuan analisis terhadap berbagai masalah yang dihadapi dalam kehidupan sehari-hari. Temuan penelitian ini mendukung hasil penelitian Hasanah, dkk. (2021), bahwa LKPD dapat meningkatkan keterampilan berpikir kritis pada materi pencemaran lingkungan. Basri, dkk.(2020) mengungkapkan bahwa LKPD dapat meningkatkan pemahaman konsep aljabar dengan kategori valid, praktis, dan efektif. Temuan penelitian ini sejalan dengan temuan Setyanto, dkk., (2015) bahwa LKPD dapat menumbuhkan karakter kemandirian peserta didik SMP sebesar $82,02 \%$. Selanjutnya, diungkapkan LKPD dapat memperkuat dan menunjang tujuan pembelajaran dan ketercapaian indikator serta kompetensi dasar dan kompetensi inti yang sesuai kurikulum berlaku, serta membantu peserta didik untuk mencapai tujuan pembelajaran (Katriani, dkk., 2012).

Hasil analisis awal bahwa pembelajaran Pencemaran Lingkungan di sekolah sudah dibelajarkan dengan baik, namun perumusan indikator pembelajarannya terbatas pada kognitif 1 (C1) dan kognitif 2 (C2). Padahal kompetensi dasar dalam kurikulum yang berlaku mengharapkan kemampuan peserta didik untuk melakukan analisis (C4) terhadap objek belajar materi Pencemaran Lingkungan. Pada pertemuan awal dalam proses pembelajaran hanya satu orang dari 22 peserta didik yang aktif merespons materi diskusi di kelas, yang masuk katagori kemampuan menganalisis sebesar 0,045 \% lainnya belum menunjukkan kemampuan analisis. Oleh sebab itu, perlu dikembangkan pembelajaran melalui LKPD berbasis masalah pada materi pencemaran lingkungan. Materi pencemaran lingkungan membahas lingkungan yang tidak sehat, mengandung udara kotor, berbau dan berakibat mengganggu saluran pernapasan manusia. Penyebabnya antara lain tidak tersedia tempat sampah mengakibatkan sampah menumpuk dan berserakan dimana-mana, tidak ada saluran air yang baik akibatnya aliran air tidak lancar karena tersumbat oleh sampah, tidak terdapat tumbuhan sehingga lingkungan menjadi gersang. Jika 
udara, tanah, dan air di suatu tempat berubah menjadi tidak sehat maka terjadi pencemaran dilingkungan .

Fenomena yang dikemukakan pada karakteristik pencemaran lingkungan diharapkan dapat mengubah kesadaran peserta didik melalui proses pembelajaran yang berhubungan dengan peristiwa pencemaran lingkungan. Salah satu usaha untuk melatih dan membelajarkan peserta didik melalui LKPD inovatif yang dikembangkan dalam penelitian ini. Keunggulan LKPD berbasis masalah dapat dijadikan panduan belajar peserta didik dan guru melakukan kegiatan belajar mengajar, belajar berpusat pada kegiatan peserta didik sendiri sehingga dapat mendorong peserta didik untuk berpikir kreatif. Ada kemampuan kreatif, analisis dan kritis serta mandiri memungkinkan peserta didik untuk mampu mengatasi masalah dalam kehidupan sehari-hari. Produk penelitian ini yang digunakan telah di validasi oleh validator tentang validitas, kepraktisan dan keefektifan. Penggunaan LKPD inovatif berdampak dapat meningkatkan kemampuan analisis terhadap materi Pencemaran Lingkungan di kelas X-IIS N-Gain sebesar 0,42 berada pada kategori sedang, sedangkan di kelas X-MIPA N-Gain sebesar 0,86 berada pada kategori tinggi.

\section{METODOLOGI PENELITIAN}

Jenis penelitian, metode penelitian, instrumen penelitian dan teknik analisis data diuraikan pada tabel 1 berikut.

Tabel 1. Desain penelitian

\begin{tabular}{ccll}
\hline $\begin{array}{c}\text { Jenis } \\
\text { penelitian }\end{array}$ & $\begin{array}{c}\text { Metode } \\
\text { penelitian }\end{array}$ & Instrumen penelitian & Teknik analisis \\
\hline $\begin{array}{l}\text { Pengemban } \\
\text { gan inovatif }\end{array}$ & Model ADDIE & Soal tes kemampuan & N-Gain untuk \\
& & analisis & menganalisis \\
& & Lembar observasi & kemampuan analisis \\
& & LKPD & Statistik deskritif \\
(menggunakan rerata \\
& & RPP & dan persentase) \\
& & \\
& & VowerPoint &
\end{tabular}

\section{HASIL PENELITIAN DAN PEMBAHASAN}

Berisi judul "Pengembangan Lembar Kerja Peserta Didik Berbasis Masalah Untuk Meningkatkan Kemampuan Analisis Pada Materi Pencemaran Lingkungan Di Sekolah Lanjutan." Tim penulis, gambar berbagai fenomena yang berhubungan dengan pencemaran lingkungan, Reviewer dan Editor.

LKPD Inovatif materi pencemaran lingkungan 


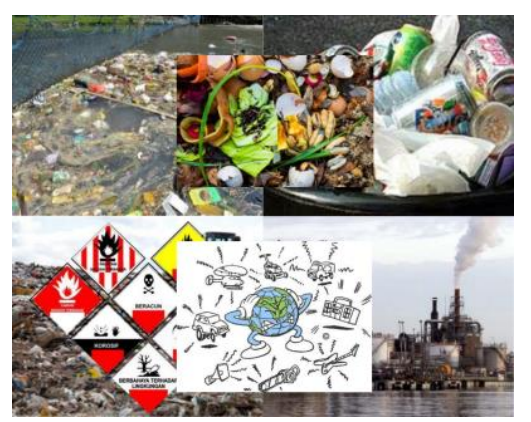

Sumber gambar yang digunakan dalam sampul LKPD

Kata pengantar berisi tujuan dikembangkannya LKPD, untuk memudahkan peserta didik dalam memahami dan menganalisis meteri, serta menumbuhkan kemandirian peserta didik.

Daftar isi halaman depan, halaman pengesahan, kata pengantar, daftar isi, pendahuluan, lembar kegiatan peserta didik, ucapan terimakasih, daftar pustaka

Hasil analisis awal pembelajaran materi pencemaran lingkungan pada rancangan pembelajaran di sekolah ditemukan indikator. 3.8.1 menjelaskan perubahan lingkungan, 3.8.2 menjelaskan pelestarian lingkungan, 3.8.3 menjelaskan limbah dan daur ulang limbah. Kompetensi Dasar (KD) yang terdapat pada kurikulum yang berlaku 3.8 menganalisis terjadinya pencemaran lingkungan dan dampaknya bagi ekosistem. Pengembangan lembar kerja peserta didik untuk membimbing peserta didik memahami dan menganalisis konsep materi dari fenomena lingkungan nyata dalam kehidupan sehari-hari, membantu mengembangkan kemampuan menganalisis, mendeteksi, mendiagnosis, menguji, memecahkan, mengkorelasikan, mendiagramkan, menyimpulkan, menemukan, dan melatih, sesuai kata kerja operasional (KKO) pada jenjang kemampuan menganalisis (C4) Taksonomi Bloom.

Lembar kerja peserta didik berisi kegiatan perubahan lingkungan, pelestarian lingkungan, limbah dan daur ulang limbah. Adanya respons guru dan validator/pengamat, peneliti, peserta didik terhadap bentuk lembar kerja peserta didik berbasis masalah yang inovatif bersifat positif.

Daftar pustaka berisi daftar referensi dalam pembuatan LKPD pencemaran lingkungan berbasis masalah materi pencemaran lingkungan. LKPD yang dikembangkan disusun dari penggabungan beberapa sumber belajar peserta didik seperti buku, artikel online, Benime dari internet.

Kontribusi Lembar Kerja Peserta Didik Berbasis Masalah untuk Meningkatkan Kemampuan Analisis Peserta Didik pada Materi Pencemaran Lingkungan 


\section{Hasil Belajar}

Hasil belajar peserta didik kelas X-IIS Peminatan melalui tes setelah kegiatan berlangsung dilaksanakan memperoleh skor rata-rata sebesar 72,63, sedangkan di kelas X-MIPA memperoleh skor rata-rata sebesar 89,62.

\section{Kemampuan Analisis}

\section{Kemampuan Analisis Peserta Didik melalui Lembar Kerja Berbasis Masalah} yang Dikembangkan di Kelas X

Hasil penelitian terhadap kemampuan analisis I, peserta didik di kelas X-IIS Peminatan jumlah skor 997 dengan rata-rata sebesar 52,47. Analisis II jumlah skor 1380 dengan rata-rata sebesar 72,63. Data dapat dilihat pada Gambar 4 berikut.

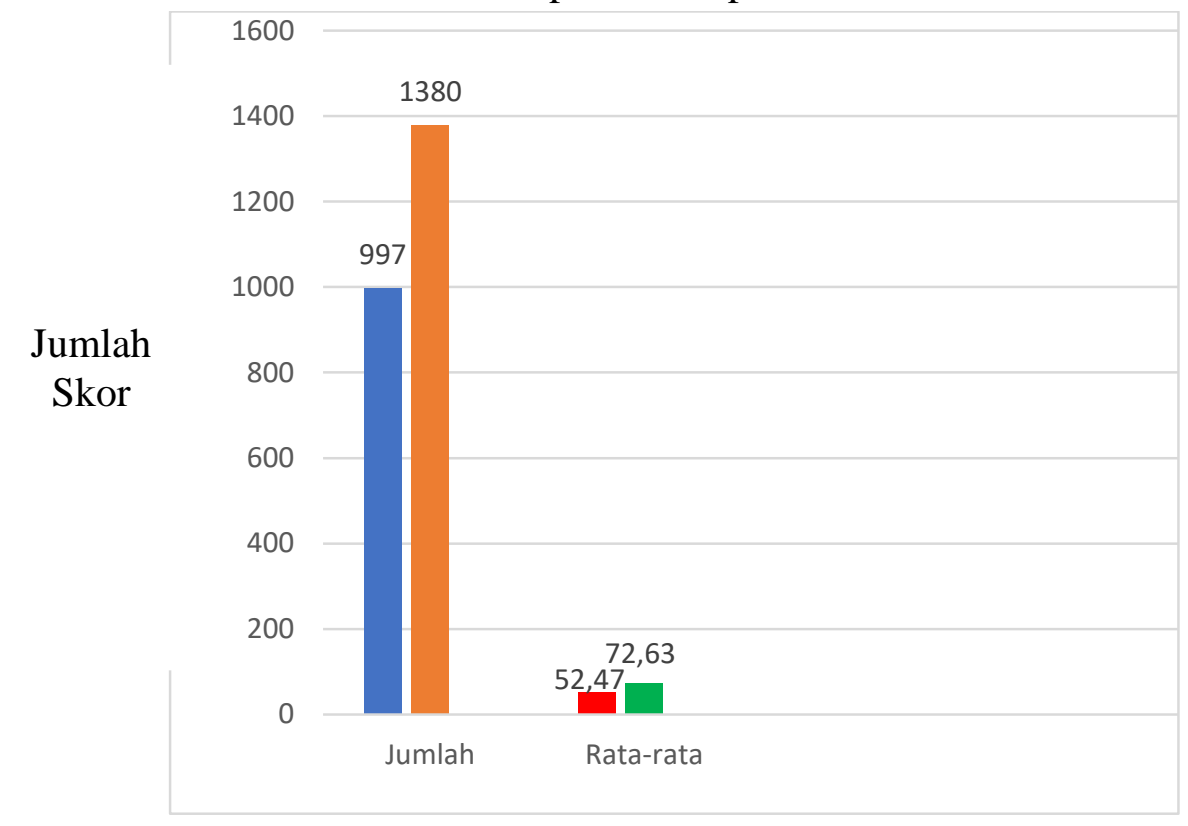

Gambar 4. Grafik Hasil Analisis Data Rata-rata Kemampuan Peserta Didik Belajar dengan Menggunakan Lembar Kerja Berbasis Masalah Di Kelas X-IIS Peminatan SMA Kristen Palangka Raya Tahun Ajaran 2021

\section{Kemampuan Analisis Peserta Didik melalui Lembar Kerja Berbasis Masalah} yang Dikembangkan di Kelas X

Hasil penelitian terhadap kemampuan analisis I, peserta didik di kelas XMIPA Peminatan jumlah skor 360 dengan rata-rata sebesar 27,69. Analisis II jumlah skor 1165 dengan rata-rata sebesar 89,62. Data dapat dilihat pada Gambar 5 berikut. 


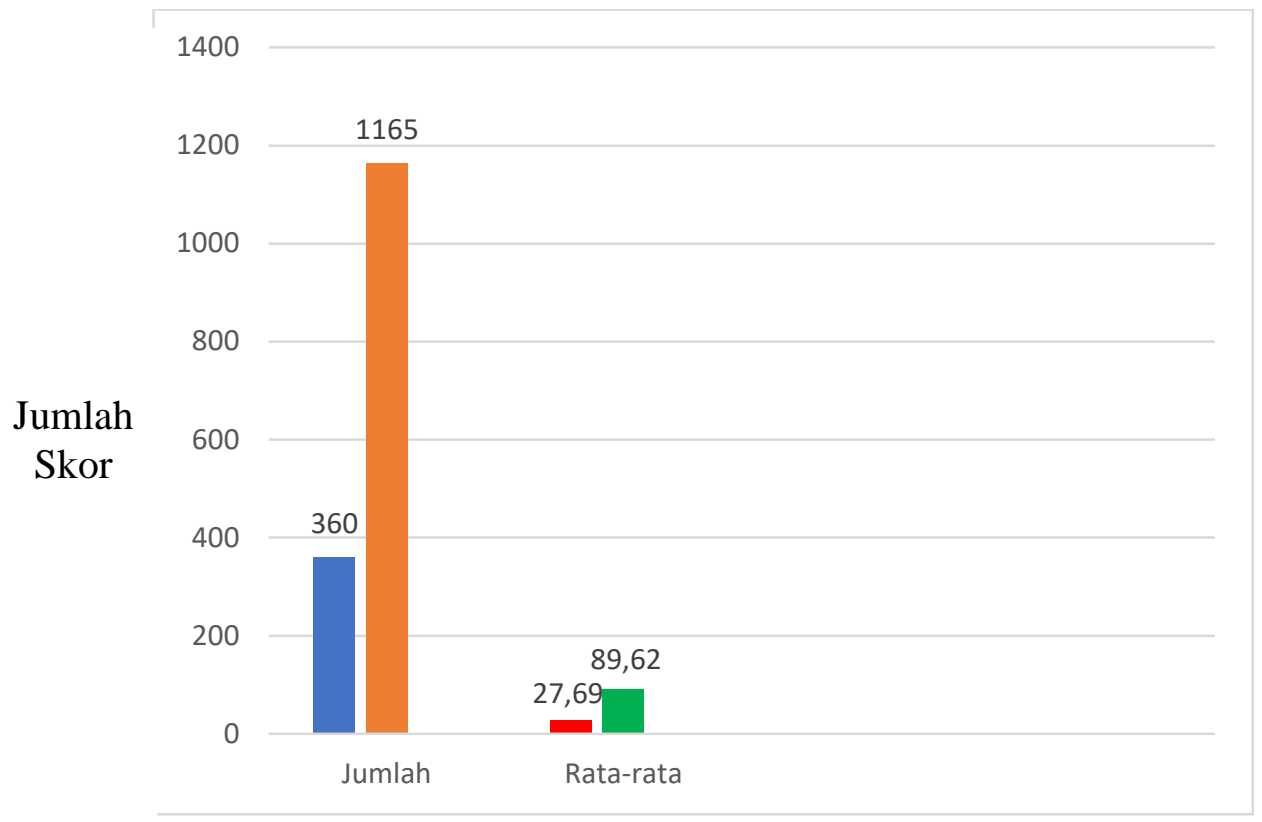

Gambar 5. Grafik Hasil Analisis Data Rata-rata Kemampuan Peserta Didik Belajar dengan Menggunakan Lembar Kerja Berbasis Masalah Di Kelas X MIPA SMA Kristen Palangka Raya Tahun Ajaran 2021

\section{Peningkatan Kemampuan Analisis Peserta Didik melalui Lembar Kerja Berbasis Masalah yang Dikembangkan di Kelas X-IIS Peminatan dan Kelas X-MIPA SMA Kristen Palangka Raya}

Hasil penelitian terhadap kemampuan analisis peserta didik belajar dengan menggunakan lembar kerja berbasis masalah yang dikembangkan pada materi pencemaran lingkungan di kelas X-IIS Peminatan dan X-MIPA, diperlihatkan pada Gambar 3 berikut. Data selengkapnya dapat dilihat pada Lampiran.

Berdasarkan Gambar 4 Kelas X-IIS peminatan memperlihatkan bahwa terjadi peningkatan sebesar 0,42 kategori sedang. Temuan ini dimaknai bahwa LKPD berbasis masalah dapat meningkatkan kemampuan analisis peserta didik pada materi pencemaran lingkungan di kategori sedang. Walaupun ada temuan dalam penelitian ini pada tes hasil pertemuan pertama $0,32 \%$ peserta didik tidak menyerahkan hasil analisis pada waktu yang telah ditentukan dengan alasan gangguan jaringan, sehingga diberi skor 0 (nol). Pada tes hasil pertemuan kedua $0,05 \%$ peserta didik tidak menyerahkan hasil analisis pada waktu yang telah ditentukan diberi skor 0 (nol). Peserta didik menyerahkan hasil tes pada pertemuan kedua 0,95\% dari 19 orang. Kesimpulan: kemampuan analisis dalam bentuk pemecahan masalah pencemaran lingkungan peserta didik kelas X-IIS Peminatan SMA Kristen Palangka Raya Tahun Ajaran 2021 terjadi peningkatan dengan NGain 0,42 termasuk kategori sedang. 


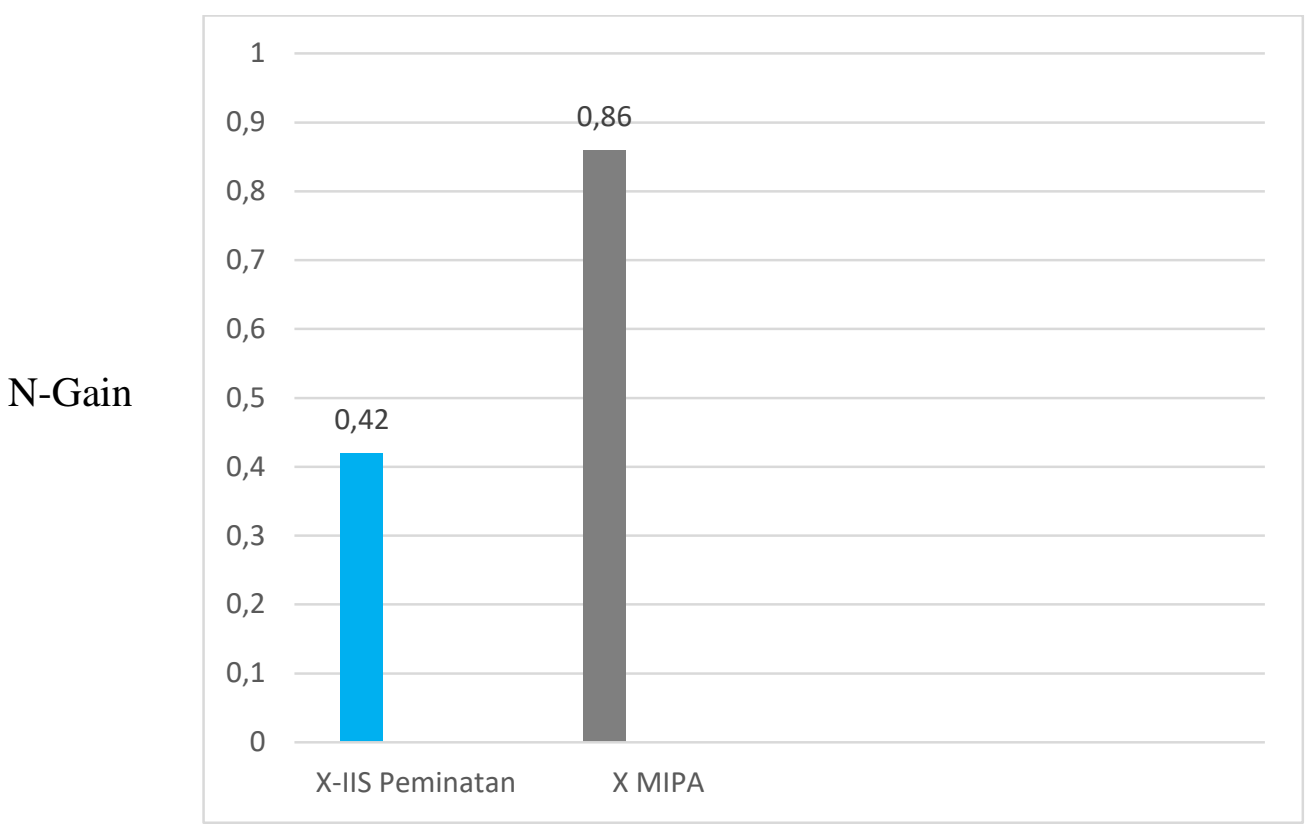

Gambar 6. Grafik N-Gain Hasil Kemampuan Peserta Didik dalam Menganaslisis Masalah Materi Pencemaran Lingkungan dengan Menggunakan Lembar Kerja yang Dikembangkan Di Kelas X-IIS Peminatan dan X MIPA SMA Kristen Palangka Raya Tahun Ajaran 2021

Berdasarkan Gambar 6 kelas X-MIPA memperlihatkan bahwa terjadi peningkatan 0,86 kategori tinggi. Temuan ini dimaknai bahwa LKPD berbasis masalah dapat meningkatkan kemampuan analisis peserta didik pada materi pencemaran lingkungan di kategori tinggi. Walaupun ada temuan dalam penelitian ini pada tes hasil pertemuan pertama $0,62 \%$ peserta didik tidak menyerahkan hasil analisis pada waktu yang telah ditentukan dengan alasan gangguan jaringan, sehingga diberi skor 0 (nol). Pada tes hasil pertemuan kedua semua peserta didik menyerahkan hasil analisis pada waktu yang telah ditentukan. Kesimpulan: kemampuan analisis dalam bentuk pemecahan masalah pencemaran lingkungan peserta didik kelas X-MIPA SMA Kristen Palangka Raya Tahun Ajaran 2021 terjadi peningkatan dengan $\mathrm{N}$-Gain 0,86 termasuk kategori tinggi.

\section{Pembahasan}

Kemampuan analisis dalam bentuk pemecahan masalah pencemaran lingkungan terjadi peningkatan dengan N-Gain 0,42 termasuk kategori sedang, disebabkan pada tes kegiatan pertama 0,32\% tidak terukur kemampuan analisis dengan alasan ada gangguan jaringan. Kelas X-MIPA terjadi peningkatan dengan $\mathrm{N}$-Gain 0,86 termasuk kategori tinggi disebabkan pada tes kegiatan pertama 0,62\% di kelas X-MIPA yang tidak terukur kemampuan analisis dengan alasan ada gangguan jaringan. Peristiwa ini bagi peneliti sulit untuk mendeteksi kebenarannya disebabkan proses pembelajaran berlangsung secara daring via Zoom meeting dengan bantuan media video, powerpoint (PPt) digunakan guru secara langsung, 
dan LKPD berbasis masalah pada materi pencemaran lingkungan, sementara peserta didik belajar jarak jauh dari rumah masing-masing. Alasan lain, dikemukakan disebabkan peserta didik berada di Kampung yang tidak terjangkau dalam jaringan (daring) berdasarkan informasi dari guru di SMA Kristen.

Pelaksanaan proses pembelajaran berdasarkan hasil pengamatan tim pengamat (guru, dosen, mahasiswa, dan respons peserta didik) bahwa proses pembelajaran sudah dilaksanakan dengan sangat baik. Penyebabnya, pelaksanaan proses pembelajaran telah dipersiapkan perangkat pembelajaran yang lengkap dan relevan antara perangkat tersebut. Perangkat pembelajaran yang dipersiapkan telah divalidasi. Fakta ini sejalan dengan Prastowo (2011) bahwa LKPD berfungsi sebagai panduan belajar, memudahkan peserta didik dan guru melakukan kegiatan belajar mengajar. LKPD didefinisikan sebagai bahan ajar cetak berupa lembarlembar kertas yang berisi materi, ringkasan, dan petunjuk-petunjuk pelaksanaan tugas yang harus dikerjakan oleh peserta didik, yang mengacu pada kompetensi dasar yang dicapai. Tujuan belajar sesuai dengan KD. Kelengkapan lainnya adalah alat dan bahan, jika kegiatan belajar memerlukan alat dan bahan, maka dituliskan alat dan bahan yang diperlukan. Prosedur kerja, berisi petunjuk kerja untuk peserta didik yang berfungsi mempermudah peserta didik melakukan kegiatan belajar. Tabel data, berisi tabel di mana peserta didik dapat mencatat hasil pengamatan atau pengukuran. Untuk kegiatan yang tidak memerlukan data bisa diganti dengan tabel/kotak kosong yang dapat digunakan peserta didik untuk menulis, menggambar atau berhitung. Bahan diskusi, berisi pertanyaan-pertanyaan yang menuntun peserta didik melakukan analisis masalah/data dan melakukan konseptualisasi.

LKPD bersama model problem based learning (PBL) memberi kesempatan kepada peserta didik untuk lebih mengeksplorasikan hasil belajar berdasarkan kemampuannya sehingga tercipta belajar lebih mandiri dan hal ini akan mengubah orientasi belajar yang semula berpusat pada guru, kemudian berubah menjadi berpusat pada kegiatan peserta didik sendiri. Hal ini didukung Atasoy dalam Celikler, 2010, bahwa LKPD sebagai alat pokok yang terdiri dari langkah dan proses yang dibutuhkan oleh peserta didik dan membantu peserta didik untuk membentuk ilmu pengetahuan dan berpartisipasi penuh pada seluruh kegiatan kelas dalam waktu yang sama. Sejalan juga dengan hasil penelitian Pariska, et al., (2012), bahwa penerapan pembelajaran menggunakan LKPD berbasis PBL dapat mendorong peserta didik untuk berpikir kreatif. Hasil penelitian Ozmen dan Yildirim, 2005 mendukung, bahwa pembelajaran dengan menggunakan LKPD lebih efektif untuk meningkatkan hasil belajar peserta didik dibandingkan pembelajaran dengan model konvensional. Penelitian yang dilakukan oleh Indriani, dkk., 2014 menyatakan bahwa pembelajaran dengan menggunakan LKPD dapat meningkatkan hasil belajar peserta didik.

LKPD yang diberikan kepada peserta didik berfungsi untuk melakukan pengamatan, sehingga peserta didik terbantu memahami konsep terkait. Hal ini 
sejalan dengan penelitian Nidyasafitri, Serevina, dan Rustana (2017) yang mengatakan LPKD berbasis masalah dapat membantu peserta didik memahami konsep materi, baik secara teori maupun dalam peristiwa nyata yang sering terjadi dalam kehidupan sehari-hari.

Peserta didik diberikan kesempatan menganalisis masalah untuk merangsang berpikir tingkat tinggi dalam situasi yang berorientasi pada masalah dunia nyata (Rusman, 2012). Model PBL digunakan untuk mengamati permasalahan nyata yang ditemui di lingkungan sebagai dasar untuk memperoleh pengetahuan dan konsep melalui berpikir kritis dan memecahkan masalah (Fakhriyah, 2014). LKPD yang dikembangkan berbasis masalah berisi suatu gambaran mengenai materi yang diberikan secara tersirat berupa artikel dan peserta didik harus menemukan permasalahan yang ada serta mengaitkan dengan materi disertai dengan solusi sesuai pemikiran peserta didik. LKPD yang diberikan guru di awal pembelajaran memberikan sebuah konflik kognitif yang bisa terjadi melalui proses belajar atau pengetahuan diri peserta didik (pengetahuan awal dengan memahami masalah). Konflik kognitif yang dialami oleh peserta didik, pada saatnya, membantu peserta didik untuk membangun pengalaman atau pengetahuannya. Kelemahan pelaksanaan penelitian ini, karena secara online, maka sulit memantau penyebab peserta didik yang tidak hadir hanya terbatas pada informasi dari guru.

\section{KESIMPULAN}

Lembar kerja peserta didik berbasis masalah hasil pengembangan dapat mengaktifkan peserta didik untuk menganalisis masalah pada materi pencemaran lingkungan. LKPD berkontribusi sangat baik sebagai media dan sumber belajar bagi peserta didik. Lembar kerja peserta didik berbasis masalah dapat meningkatkan kemampuan peserta didik kelas X-MIPA menganalisis masalah pada materi pencemaran lingkungan dengan $\mathrm{N}$-Gain 0,86 kategori tinggi, sedangkan di kelas X-IIS Peminatan terjadi peningkatan kemampuan analisis dengan N-Gain 0,42 berada pada kategori sedang. Implikasi bagi pendidikan bahwa LKPD berbasis masalah dapat meningkatkan kemampuan analisis peserta didik pada materi pencemaran lingkungan, bahkan dapat meningkatkan kemampuan analisis terhadap berbagai masalah yang dihadapi dalam kehidupan sehari-hari, disarankan guru dapat memanfaatkan LKPD inovatif dalam proses pembelajaran.

\section{DAFTAR RUJUKAN}

Celikler, D. 2010. The Effect Of Worksheets Developed For The Subject Of Chemical Compounds On Student Achievement And Permanent Learning. The International Journal Of Research In Teacher Education, 1(1):42-51

Indriani, W., Murtiani, \& Gusnaedi. 2014. Pengaruh Penerapan Lkpd Berbasis Strategi Pembelajaran Peningkatan Kemampuan Berpikir (Sppkb) Terhadap 
Keterampilan Berpikir Kreatif Peserta Didik. Pillar Of Physics Education. 2: $145-152$.

Nidyasafitri, Farah, Vina Serevina, Dan Cecep E. Rustana. "Pengembangan Lks Berbasis Pbl (Problem Based Learning) Pad Pokok Bahasan Momentum Dan Impuls Fisika Sma Kelas Xi." Jurnal Wahana Pendidikan Fisika, 2017, $51-57$.

Ozmen, H., \& N. Yidirim. 2005. Effect of Work Sheet on Student's Success: Acids and Based Sample. Jurnal of Turkish Science Education 2(2): 10-13.

Pariska, I. S., S. Elniati, \& Syafriandi. 2012. Pengembangan Lembar Kerja Peserta Didikberbasis Masalah. Jurnal Pendidikan Matematika, 1(1): 75-80.

Prastowo A. (2011). Panduan Kreatif Membuat Bahan Ajar Inovatif: Menciptakan Metode Pembelajaran Yang Menarik Dan Menyenangkan. Yogyakarta: Diva Press

Rusman, 2012. Model Model Pembelajaran. Jakarta: Raja Grafindo Persada. 